\title{
FEMORAL - INTERNAL ILIAC BYPASS IN AORTOILIAC ANEURYSMS ENDOVASCULAR REPAIR
}

\author{
Petr Utíkal ${ }^{\mathrm{a}}$, Martin Köcher ${ }^{\mathrm{b}}$, Petr Bachleda ${ }^{\mathrm{a}}$, Petr Dráč ${ }^{\mathrm{a}}$, Marie Černác, Eva Buriánkovác, \\ Lucie Lubuškád
}

\author{
a $2^{\text {nd }}$ Clinic of Surgery, Teaching Hospital Olomouc, Czech Republic \\ ${ }^{b}$ Clinic of Radiology, Teaching Hospital Král. Vinohrady Praha \\ c Clinic of Radiology, Teaching Hospital Olomouc \\ ${ }^{d} I^{\text {st }}$ Clinic of Surgery, Teaching Hospital Olomouc \\ e-mail:petr.utikal@fnol.cz
}

Received: April 5, 2004; Accepted: June 11, 2004

Key words: Aortoiliac aneurysm/Endovascular repair/Ischaemic complications/Femoral-internal iliac bypass

The authors describe femoral - internal iliac bypass creation to remove ischemic complications in aortoiliac aneurysm endovascular repair. Based on a good experience with bypass in 6 patients they recomend its preventive indication when both internal iliac arteries are overstented.

\section{INTRODUCTION}

Indication for abdominal aortic aneurysm (AAA) endovascular repair (EVAR) depends on AAA morphology. In patient selection for endovascular grafting helps AAA morphological classification ${ }^{1,2}$. Extension of the aneu-

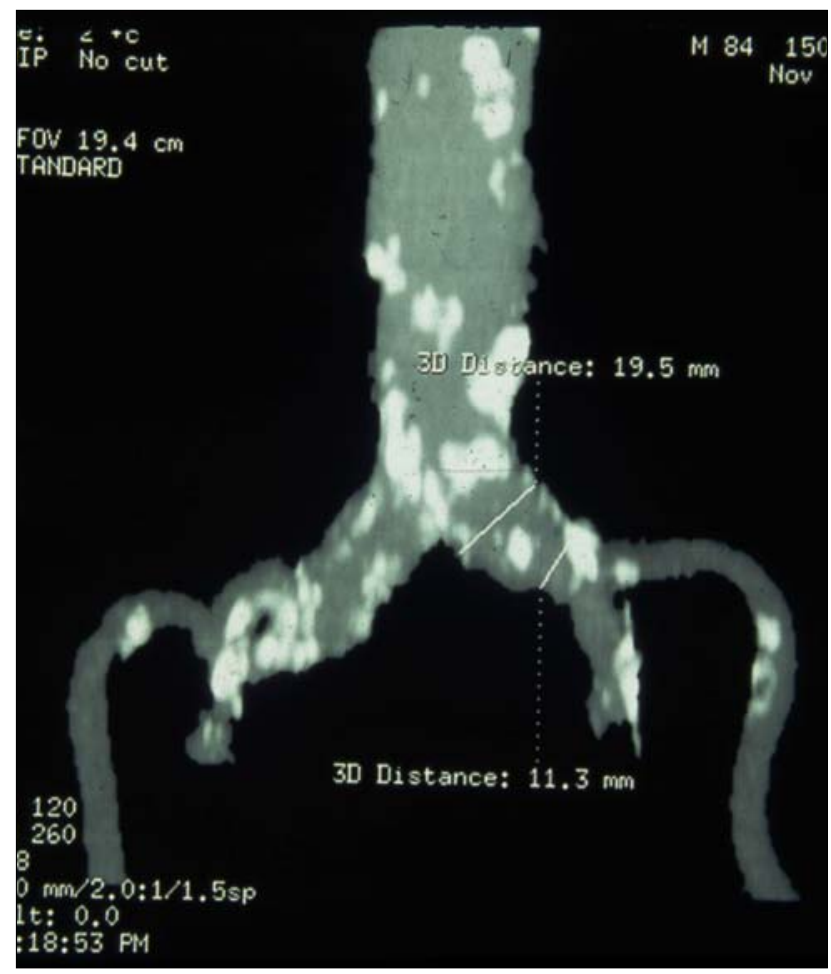

Fig. 1. AAA extending to the iliac bifurcation - TYPE II C/2 according to modified Schumacher - TYPE D, E to EUROSTAR (CTA) rysm to the iliac bifurcation ( aortoiliac AAA of type II C according to Schumacher - type D,E to EUROSTAR classification) is considered to be one of the exclusion criteria for $\mathrm{EVAR}^{3}$. The stentgraft must be extended into the external iliac artery. The internal iliac artery is excluded from the direct blood flow and its origin must be occluded to prevent retrograde endoleak. Artificial occlusion of to this time open both internal iliac arteries may be tolerated, but with concomitant exclusion of inferior mesenteric artery and lumbal arteries by aortic stentgraft the risk of severe

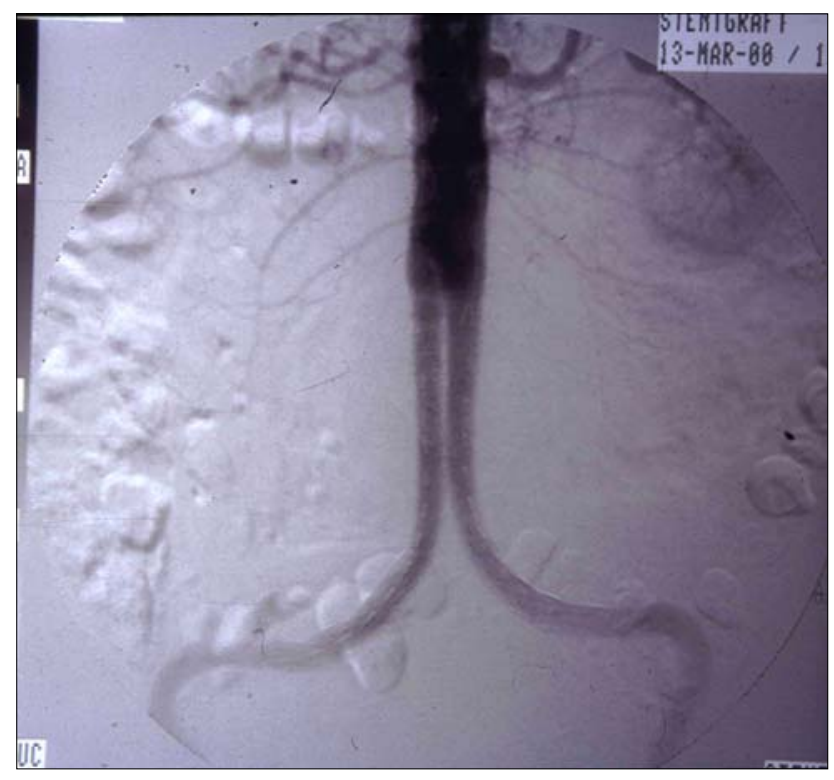

Fig. 2. Succesful exclusion by BIFURCATED TYPE of ELLA STENTGRAFT, both iliac limbs are anchored to the external IAs, the origins of internal IAs are ligated (DSA) 




Fig. 3. SCHEME of AAA of type II $\mathrm{C} / 2$ excluded by bifurcated stentgraft with femoral - internal iliac bypass

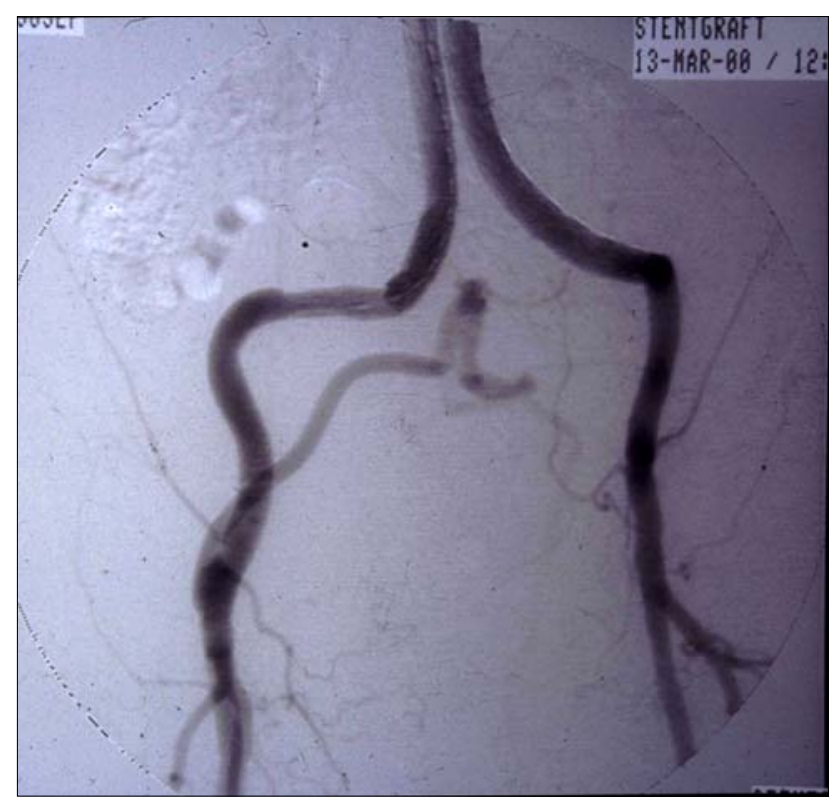

Fig. 5. Patent FEMORAL - INTERNAL ILIAC BYPASS at the right side (DSA)

ischaemia can be significant ${ }^{3-7}$. Concomitant anatomical factors, however, are of importance. The basic condition is patend superior mesenteric artery ${ }^{3}$.

\section{METHOD}

From April 1996 to April 2004 we treated endovascularly 140 infrarenal AAA with Czech made ELLA stentgraft system $^{8-11}$. In 25 patients the aneurysmal dilatation of the common iliac artery necessitated extension of the

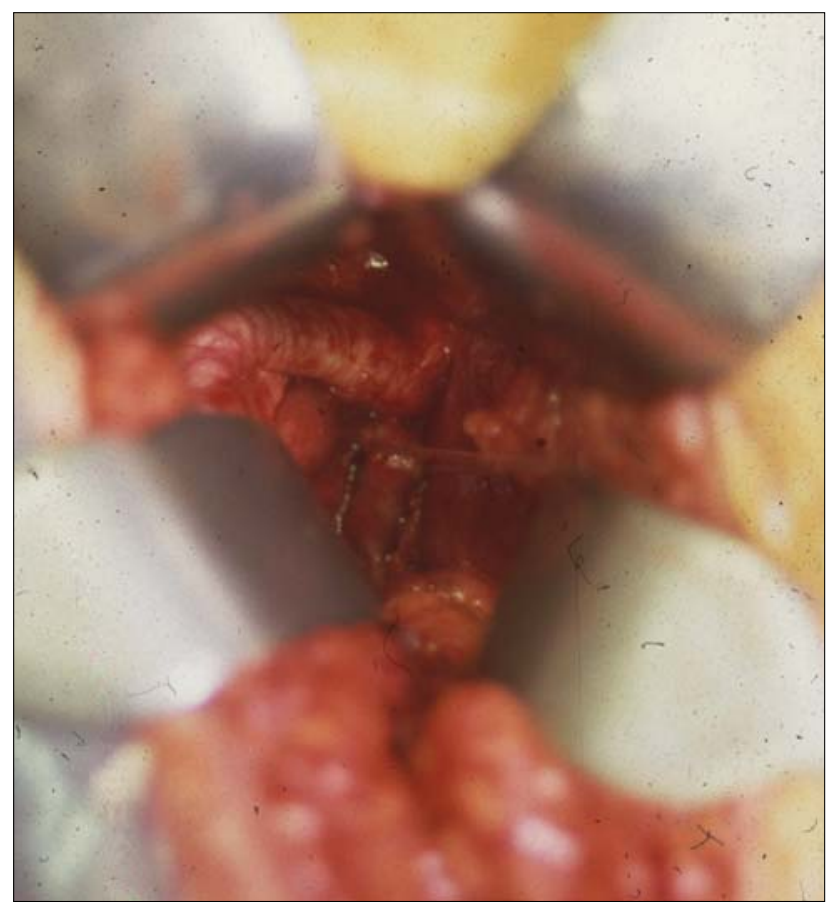

Fig. 4. GROIN ACCESS to the internal iliac artery ( PEROPERATIVE VIEW)

device across the internal iliac artery origin. In 12 of these patients (AAA of type II C/2 ) the internal iliac artery origin was overstented and then occluded on both sides (Fig. 1, 2). Severe ischemic complications (colorectal and spinal cord ischemia) did not occur, but the first 6 patients had indefinite pelvic discomfort and hip-buttock claudications.

In the last 6 patients one of the two ligated internal iliac arteries was transsected and anastomosed using ePTFE prosthesis interposition with common femoral artery from groin access (Fig. 3, 4).

There were no procedure related complications. All the bypasses are primarily patent to date and the patients are ischemic symptom free (Fig. 5).

\section{CONCLUSION}

From our point of view aortoiliac aneurysms (type II C according to Schumacher - type D,E to EUROSTAR) are not contraindications for EVAR.

One patent internal iliac artery with direct blood flow (in the type II C/1 of AAA) is quite sufficient.

In patients where both internal iliac arteries have to be ligated at their origin (type II C/2 of AAA) we recommend unilateral femoral-internal iliac bypass from groin access as a simple, safe and effective method to prevent severe ischemic complications and to remove ischemic discomfort. 


\section{REFERENCES}

1. Schumacher H, Allenberg JR, Eckstein HH. (1996) Morphological classification of abdominal aortic aneurysm in selection of patients for endovascular grafting. Br J Surg 83, 949-950.

2. Harris PL, Buth J, Miahle C, Myhre HO, Norgren L. (1997) The need for clinical trials of endovascular abdominal aortic aneurysm sten-graft repair: The EUROSTAR project. J Endovasc Surg 4, 72-77.

3. Henretta JP, Karch LA, Hodgson KJ, Mattos MA, Ramsey DE, McLafferty R, Sumner DS. (1999) Special iliac artery considerations during aneurysm endografting. Am J Surg 178, 212-218.

4. Björck M, Tröeng T, Berqvist D. (1997) Risk factors for intestinal ischemia after aortoiliac surgery. A combined cohort and casecontrol study of 2824 operations. Eur J Vasc Endovas Surg 13, 531-539.

5. Cuypers P, Nevelsteen A, Buth J, Hamming J, Stockx L, Lacroix H, Tieelbek A. (1999) Complications in endovascular repair of abdominal aortic aneurysms: a risk factor analysis. Eur J Vasc Endovasc Surg 18, 245-252.
6. Hands LJ, Collin J, Lamont P. (1991) Observed incidence of paraplegia after infrarenal aorticaneurysm repair. Br J Surg 78, 999-1000.

7. Papadopoulos CD, Mancini HW, Marino MWA. (1974) Ischemic necrosis of the colon following aortic aneurysmectomy. J Cardiovasc Surg 15, 494-500.

8. Köcher M, Utíkal P, Sekanina Z, Bachleda P, Novotný J. (1998) Léčba AAA bifurkačními stentgrafty Ella - první zkušenosti. Rozhl Chir 77, 260-266.

9. Utíkal P, Köcher M, Bachleda P, Novotný J, Ürge J, Dráč P. (2000) Tříleté zkušenosti se stentgraftingem AAA ve FN UP v Olomouci. Prakt flebol 9, 175-179.

10. Utíkal P, Köcher M, Bachleda P, Dráč $\mathrm{P}$, Buriánková E, Kojecký Z, Ürge J. (2001) Léčba AAA na prèlomu tisíciletí - stentgrafting - role cévního chirurga. Prakt Flebol 10, 111-113.

11. Köcher M, Utíkal P, Buriánková E, Koutná J, Bachleda P, Novotný J, Heřman M, Benýšek V, Bučil J, Černá M. (2001) Čtyřleté zkušenosti se stentgraftem Ella v endovaskulární léčbě AAA. Čes Radiol 55, 159-166. 